\title{
Voting Shift in the November 2014 Local Elections in Taiwan
}

Strong rebuke to Ma Ying-jeou's government and policies and landslide victory for the DPP.

Frank Muyard

\section{(2) OpenEdition}

\section{Journals}

Electronic version

URL: http://journals.openedition.org/chinaperspectives/6657

DOI: 10.4000/chinaperspectives.6657

ISSN: 1996-4617

\section{Publisher}

Centre d'étude français sur la Chine contemporaine

\section{Printed version}

Date of publication: 1 March 2015

Number of pages: 55-61

ISSN: 2070-3449

\section{Electronic reference}

Frank Muyard, « Voting Shift in the November 2014 Local Elections in Taiwan », China Perspectives [Online], 2015/1 | 2015, Online since 01 January 2017, connection on 15 September 2020. URL : http:// journals.openedition.org/chinaperspectives/6657 


\title{
Voting Shift in the November
}

\section{Local Elections in Taiwan}

\author{
Strong rebuke to Ma Ying-jeou's government and policies and landslide victory for \\ the DPP.
}

FRANK MUYARD

$\mathrm{O}$ 29 November 2014, Taiwan held the largest series of local elections in its history, in a nine-in-one format combining polls for 11,130 positions, ranging from mayors of municipalities and cities (zhixiashi/shizhang 直轄市/市長), county magistrates (xianzhang 縣長), city and county councillors (shi/xian yihuiyuan 市/縣議會員), township chiefs (zhenzhang 鎮長, xiangzhang 鄉長), and village and borough chiefs (cunzhang 村長, lizhang 里長), to indigenous district chiefs and councillors (zhixiashi shandi yuanzhumin quzhang, qumin daibiao 直轄市山地原住民區長, 區民 代表). All were elected for four-year terms. Two-and-a-half years into the second presidential term of Ma Ying-jeou, the nation-wide elections were seen as a mid-term test for his administration and a prelude to the next legislative and presidential elections in early 2016. (1) The big prizes consisted of the six special municipalities of Taipei, New Taipei, Taichung, Tainan, Kaohsiung, and, for the first time, Taoyuan. They represent around 70\% of Taiwan's 18.5 million registered voters, with the other $30 \%$ distributed among 16 counties and cities of smaller size or more rural character.

Before the vote, four municipalities (Taipei, New Taipei, Taichung, and Taoyuan) and 12 counties and cities were held by the ruling Kuomintang (KMT) or its Blue camp allies, with a virtual monopoly over central and northern Taiwan, and only llan on the north-east coast being led by the opposition Democratic Progressive Party (DPP). The DPP mostly ruled in the south, heading the two municipalities of Tainan and Kaohsiung, along with Yunlin, Chiayi, and Pingtung counties. Due to media concentration and the national pre-eminence of the candidates, coverage of the electoral campaigning largely concentrated on the capital Taipei, where KMT candidate Sean Lien Sheng-wen 連勝文, son of the former prime minister, vice-president, and KMT chairman Lien Chan 連戰, opposed the independent candidate Ko Wen-je 柯文哲, a National Taiwan University Hospital surgeon supported by the DPP; and on the central city of Taichung, where KMT mayor Jason Hu Chih-chiang 胡志強 attempted to win a fourth term against DPP legislator Lin Chia-lung 林佳龍.

The DPP and its Green camp ally, the Taiwan Solidarity Union (TSU Taiwan tuanjie lianmeng 台灣團結聯盟), mainly campaigned on the strength of local governance - its mayors repeatedly winning top positions based on popularity and local government quality in public opinion surveys - and on support for a renewed grass-roots and democratic spirit on the heels of the Sunflower Movement of last spring. But it also surfed on the low approval rate of $\mathrm{Ma}$ and the KMT, rising social and economic inequality, and widespread anger over government corruption and housing prices. In the Blue camp, the high level of popular discontent toward the KMT administration and the way the country has been ruled, and the tepid results of its main policies, including its trumpeted cross-strait economic and political rapprochement, left the KMT candidates with few national or local policy achievements to run with. In many cases, Ma was seen as so politically toxic that candidates declined to stand with him on a public stage. In a desperate attempt, Lien Sheng-wen and the KMT tried to nationalise and polarise the campaign into a classic Blue-Green battle around cross-strait relations and identity, pushing the "save the Republic of China (ROC)" card to rally deepBlue voters and prop up their campaign. It had the mostly opposite result of showing even more clearly the disconnect between today's mainstream national Taiwanese identity and the KMT mainlander old guard such as former premiers Hau Pei-tsun 郝柏村 and Lien Chan, aggravated by repeated vulgarities and expression of contempt and racism from the latter toward native Taiwanese. (2)

\section{Overall election results}

Election turnout was $67.59 \%$, well within the average turnout for local polls since 1997. The results saw a landslide victory for the DPP and the worst defeat of the KMT in Taiwan election history in terms of both seats and vote percentage. The DPP won four municipalities (Taichung, Taoyuan, Tainan, Kaohsiung) and nine cities and counties, including symbolically significant victories in long-held KMT circumscriptions. Taichung, Tainan, and Kaohsiung were won in landslides, while the vote shares received in victories in Ilan, Changhua, Chiayi County, and Pingtung were the DPP's best records ever in local elections there. The DPP kept all its previously held mandates, incumbent or not, and snatched seven positions formerly controlled by the KMT. The cherished prize of Taipei was also won by the DPP-supported independent candidate Ko Wen-je in another landslide, leading to the worst defeat and humiliation of the KMT in the capital. All that remained in the KMT camp was New Taipei, the largest municipality in the country surrounding Taipei on all sides, but with a razor-thin victory, and the counties of

1. Legislative elections are usually held in December or January. The Presidential election has been traditionally held in March, with inauguration in May. In 2012, the legislative and presidential elections were held together on January 14, for the first time on the same day, according to the wishes of Ma and the KMT, who saw it as favorable to their chances of success. It created a fourmonth time gap between the presidential election and the inauguration, leading to heavy criticism and worries about the legitimacy of a possible lame-duck seated president during that time, a problem that was eventually avoided with the reelection of Ma. In 2016, the two elections will also be combined with the date yet to be announced. Cf. "Combined legislative, presidential elections to take place in 2016: CEC", Central News Agency, 12 February 2015. About the 2012 elections, cf. Tanguy Le Pesant, "A New Generation of Taiwanese at the Ballot Box:Young voters and the presidential election of January 2012," China Perspectives, 2012/2, pp. 71-79.

2. Alison Hsiao, "Ethnic discrimination seen in KMT attacks," Taipei Times, 21 November 2014 
Table 1 - Results of Mayoral and County Magistrate Elections, November 2014

\begin{tabular}{|c|c|c|c|c|c|}
\hline \multirow{2}{*}{ City/County } & \multirow{2}{*}{ Party } & \multirow{2}{*}{ Mayor/Magistrate } & \multicolumn{3}{|c|}{ Percentage of Votes } \\
\hline & & & DPP & KMT & Ind. \\
\hline Total Seats & & & 13 & 6 & 3 \\
\hline Total \% & & & 47.55 & 40.70 & 11.70 \\
\hline \multicolumn{6}{|l|}{ Six municipalities } \\
\hline Taipei City & Ind. * & KoWen-je & --- & 40.82 & 57.16 \\
\hline New Taipei City & KMT & Eric Chu Li-luan & 48.78 & 50.06 & 1.16 \\
\hline Taoyuan City & $\mathrm{DPP} *$ & Cheng Wen-tsang & 51.00 & 47.97 & 1.03 \\
\hline Taichung City & DPP * & Lin Chia-lung & 57.06 & 42.94 & --- \\
\hline Tainan City & DPP & William Lai Ching-te & 72.90 & 27.10 & 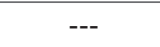 \\
\hline Kaohsiung City & DPP & Chen Chu & 68.09 & 30.89 & 1.02 \\
\hline \multicolumn{6}{|l|}{ Cities and counties } \\
\hline Keelung City & DPP * & Lin Yu-chang & 53.15 & 27.47 & 19.37 \\
\hline Yilan County & DPP & Lin Tsung-hsien & 63.95 & 36.05 & \\
\hline Hsinchu City & DPP * & Lin Chih-cien & 38.36 & 37.85 & 23.77 \\
\hline Hsinchu County & KMT & Chiu Ching-chun & --- & 46.94 & 44.82 \\
\hline Miaoli County & KMT & Hsu Yao-chang & 28.37 & 46.59 & 25.03 \\
\hline Changhua County & $\mathrm{DPP} *$ & Wei Ming-ku & 53.71 & 39.58 & 6.70 \\
\hline Nantou County & KMT & Lin Ming-chen & 49.04 & 50.96 & --- \\
\hline Yunlin County & DPP & Lee Chin-yung & 56.98 & 43.02 & --- \\
\hline Chiayi City & DPP * & Twu Shiing-jer & 51.41 & 45.50 & 3.07 \\
\hline Chiayi County & DPP & Helen Chang Hua-kuan & 63.09 & 34.09 & 2.82 \\
\hline Pingtung County & DPP & Pan Meng-an & 62.93 & 37.07 & --- \\
\hline Hualien County & Ind. & Fu Kun-chi & --- & 27.62 & 56.53 \\
\hline Taitung County & KMT & Justin Huang Chien-ting & 45.59 & 54.41 & 15.85 \\
\hline Penghu County & DPP * & Chen Kuang-fu & 55.34 & 44.66 & --- \\
\hline Kinmen County & Ind.* & Chen Fu-hai & --- & 33.35 & 52.77 \\
\hline Lienchiang County & KMT & Liu Tsen-ying & --- & 33.75 & 66.25 (KMT) \\
\hline
\end{tabular}

* Formerly held and lost by KMT. / Source: Central Election Commission.

Hsinchu, Miaoli, Nantou, Taitung, and Lienchiang (Matsu). The KMT's victories were narrow, and incumbents were defeated in Taoyuan, Taichung, Hsinchu City, Kinmen, and Matsu. Two other Blue-camp independent candidates won in Hualien and Kinmen counties.

The extent of the KMT debacle and the DPP success went beyond both camps' expectations and was a surprise to most analysts. Overall, the KMT scored only $40.70 \%$ (4,990,677 votes), its lowest ever nationwide result, which rises to $43.89 \%(5,381,874$ votes) if adding in other Blue-camp parties (New Party Xindang 新黨, People First Party Qinmindang 親民黨) and Blue-leaning independent candidates. For the DPP, this poll marks one of its best records in local elections, with $47.55 \%$ (5,830,106 votes) and an increase of 490,000 ballots in the five municipalities besides Taipei. This number underestimates DPP support, as it excludes Green-camp leaning or supported candidates such as Ko in Taipei. A more realistic figure would add, not the full count of Ko's votes, but at least the number of votes of the DPP candidate in the 2010 Taipei elections, ${ }^{(3)}$ resulting in a total of $52.67 \%(6,458,235$ votes $)$, a $4.5 \%$ rise since the last local election cycle. It does not include Green party dissidents, and could thus be seen as a minimum if virtual number. As such, it is the highest level of electoral support ever achieved by the DPP in countrywide elections, and the first time since the 2004 presidential re-election of Chen Shui-bian that the party gained an absolute majority.

A look at the new electoral map gives interesting insights into the current political landscape. The DPP-ruled circumscriptions represent more than $60 \%$ of the Taiwanese population (more if counting Taipei). The party not only controls four of the six municipalities (see below) where the majority of the urban population and enterprises are concentrated, but also totally dominates the south and centre of the country from Pingtung to Taichung, while reappearing as an important player in the north. Victories in the south were expected, although not with such large shares of the vote, including in Chiayi City, where the young female KMT candidate looked for a while as if she would be able to keep the mayoralty in the Blue camp. In Hsinchu, the DPP candidate was in a three-way race and barely won with less than $40 \%$, even though an independent candidate and former DPP mayor took

3. DPP candidate Su Tseng-chang garnered $43.81 \%$ and 628,129 votes in the 2010 Taipei election 
Table 2 - Taiwan 2014 Local Elections Six Municipalities Results

\begin{tabular}{|c|c|c|c|c|c|c|c|}
\hline & $\begin{array}{l}\text { Turnout } \\
\% / \text { votes }\end{array}$ & DPP & KMT & Ind. & $\begin{array}{c}2010 / 14 \\
\text { turnout change } \\
\% / v o t e s\end{array}$ & $\begin{array}{c}2010 / 14 \\
\text { DPP change } \\
\% / \text { votes }\end{array}$ & $\begin{array}{c}2010 / 14 \\
\text { KMT change } \\
\% / v o t e s\end{array}$ \\
\hline Taipei & $\begin{array}{c}70.46 \\
1,512,724\end{array}$ & --- & $\begin{array}{c}40.82 \\
609,932\end{array}$ & $\begin{array}{c}57.16 \\
853,983\end{array}$ & $\begin{array}{c}-0.19 \\
67,354\end{array}$ & --- & $\begin{array}{c}-14.82 \\
-187,933\end{array}$ \\
\hline New Taipei & $\begin{array}{c}61.65 \\
1,946,063\end{array}$ & $\begin{array}{c}48.78 \\
934,774\end{array}$ & $\begin{array}{c}50.06 \\
959,302\end{array}$ & $\begin{array}{c}1.16 \\
22,207\end{array}$ & $\begin{array}{c}-9.6 \\
-196,347\end{array}$ & $\begin{array}{c}1.39 \\
-70,126\end{array}$ & $\begin{array}{c}-2.54 \\
-156,234\end{array}$ \\
\hline Taoyuan* & $\begin{array}{c}62.73 \\
984,099\end{array}$ & $\begin{array}{c}51.00 \\
492,414\end{array}$ & $\begin{array}{c}47.97 \\
463,133\end{array}$ & $\begin{array}{c}1.03 \\
9,943\end{array}$ & $\begin{array}{c}9.0 \\
211,919\end{array}$ & $\begin{array}{c}5.31 \\
146,177\end{array}$ & $\begin{array}{c}-4.25 \\
66,896\end{array}$ \\
\hline Taichung & $\begin{array}{c}71.93 \\
1,506,023\end{array}$ & $\begin{array}{c}57.06 \\
847,284\end{array}$ & $\begin{array}{c}42.94 \\
637,531\end{array}$ & --- & $\begin{array}{c}-1.22 \\
59,504\end{array}$ & $\begin{array}{c}8.18 \\
148,926\end{array}$ & $\begin{array}{c}-8.17 \\
-92,753\end{array}$ \\
\hline Tainan & $\begin{array}{c}65.88 \\
996,688\end{array}$ & $\begin{array}{c}72.90 \\
711,557\end{array}$ & $\begin{array}{c}27.10 \\
264,536\end{array}$ & -- & $\begin{array}{c}-5.13 \\
-45,253\end{array}$ & $\begin{array}{c}12.49 \\
91,660\end{array}$ & $\begin{array}{c}-12.48 \\
-141,660\end{array}$ \\
\hline Kaohsiung & $\begin{array}{c}66.44 \\
1,482,425\end{array}$ & $\begin{array}{c}68.09 \\
993,300\end{array}$ & $\begin{array}{c}30.89 \\
450,647\end{array}$ & $\begin{array}{c}1.02 \\
14,925\end{array}$ & $\begin{array}{c}-6.08 \\
-88,470\end{array}$ & $\begin{array}{c}15.3 \\
172,211\end{array}$ & $\begin{array}{c}10.3 \\
131,476\end{array}$ \\
\hline
\end{tabular}

*For Taoyuan, comparison with 2009 local election. / Source: Central Election Commission.

away some Green votes. In Keelung, the DPP was facing a split KMT and won partly on citizens' fatigue and disgust with corruption-tainted past KMT administrations, but still with a solid $53 \%$ of the votes. The win in Penghu was an impressive victory for the DPP, with over $55 \%$ of the vote, but came after a continuous rise in DPP support in local and national elections, and in a year marked by a national political wave that made it ripe for the picking. DPP's party unity, good choice of candidates, and campaigns focused on local needs and good governance helped the party to expand its control north of Yunlin and for the first time to most of the central region of the country with decisive wins in Changhua and Taichung. Only Nantou, the home county of vice-president Wu Dun-yi, narrowly escaped the Green wave.

All that was left to the Kuomintang, with the exception of New Taipei, were the tiny outlying islands facing China's Fujian Province, and mostly rural and mountainous counties with smaller service and industrial sectors and an older and less active population. These locales are also characterised by a high number of Hakka, Aborigines, and concentrated waisheng communities. This voting pattern was replicated in Hualien, ruled by former PFP Fu Kun-chi 傅怅萁, as well as more locally in Taoyuan and New Taipei districts, or even in Tainan and Kaohsiung, where Hakka (less in the south) and waisheng groups increasingly constitute the main support of the KMT, together with older generations of civil servants of all backgrounds and Aborigines everywhere. This has also been true for Taipei in all previous KMT-DPP battles, but this time the presence of a non-DPP candidate and the inferior campaign by the KMT led to a reshuffling of voting groups and behaviour.

\section{Results in the six municipalities}

Detailed analysis of the results in the six municipalities shows marked changes in the fortunes of the two camps since the last local polls (see Table 2). In Taipei, with a similar turnout as in 2010 and a slightly bigger electorate, the KMT's dismal performance in vote share and numbers constitutes its lowest ever result. It indicates problems going beyond the anti-government national electoral trend and linked to a badly prepared and inexperienced KMT "princeling" candidate, who ran a polarising, backward-leaning, nasty, and gaffe-prone campaign. ${ }^{\left({ }^{4}\right)}$ Conversely, Ko Wen-je's winning percentage and total number of votes are the second highest recorded in Taipei election history, inferior only to Ma's 2002 mayoral re-election against a weak DPP candidate. It is also much higher than the best DPP score (Chen Shui-bian's 1998 re-election defeat), breaking the 700,000 vote ceiling for non-KMT candidates in Taipei for the first time, and leading to an acrossthe-board victory in all municipal districts, including those most associated with the KMT's traditional supporter groups of Mainlanders (waishengren 外省人) and civil servants, a historic and unique feat. Ko's winning coalition, while based on DPP electors who overwhelmingly supported him, went clearly beyond the Green camp to include centrist, younger, and formerly disenfranchised voters attracted by his rejection of partisan polarisation, as well as Blue voters disappointed by both Ma's national policies and the candidacy of Lien Sheng-wen. For the KMT, with a candidate and a campaign described as the worst ever, the sole consolation may be to see that its bottom level is around 610,000 votes, still high enough to build on and give hope of winning in a more favourable environment.

In New Taipei, the biggest surprises were the big drop in turnout and a very narrow victory for the KMT incumbent candidate and rising star of the party, Eric Chu Li-luan 朱立倫, who lost many votes compared to 2010, when he faced DPP chairwoman Tsai Ing-wen 蔡英文 in a tied race. A very limited campaign with no new policy platforms by Chu, combined with his pre-announced large victory in all the media and opinion polls, may have worked against higher turnout and support from the Blue camp. But with the general anti-KMT mood of the electorate, these numbers may also have been close to their maximum for a very popular mayor. It thus showed that Chu was not immune from the national protest vote against the KMT, but his personal appeal may have saved him as one of the rare KMT winners, while any other candidate would have fared worse. Bleak prospects for the KMT in New Taipei had indeed already forced his decision last spring to run for re-election for fear that the party would otherwise lose all its northern mayoral positions, against his apparent desire to run for the 2016 presidential election. The DPP candidate, former premier Yu Shyi-kun 游錫㫃, did much better than anticipated, but he also garnered fewer votes than Tsai in 2010, and a less depressed turnout or a candidate more appealing to the younger generation could have helped created another upset, since Tsai's

4. Cf. J. Michael Cole, "He Also Drank the Blood of His Patients," Thinking Taiwan, 21 November 2014, http://thinking-taiwan.com/he-also-drank-the-blood-of-his-patients/ (accessed on 26 January 2015). 
Map 1 - Taiwan 2014 Elections Map

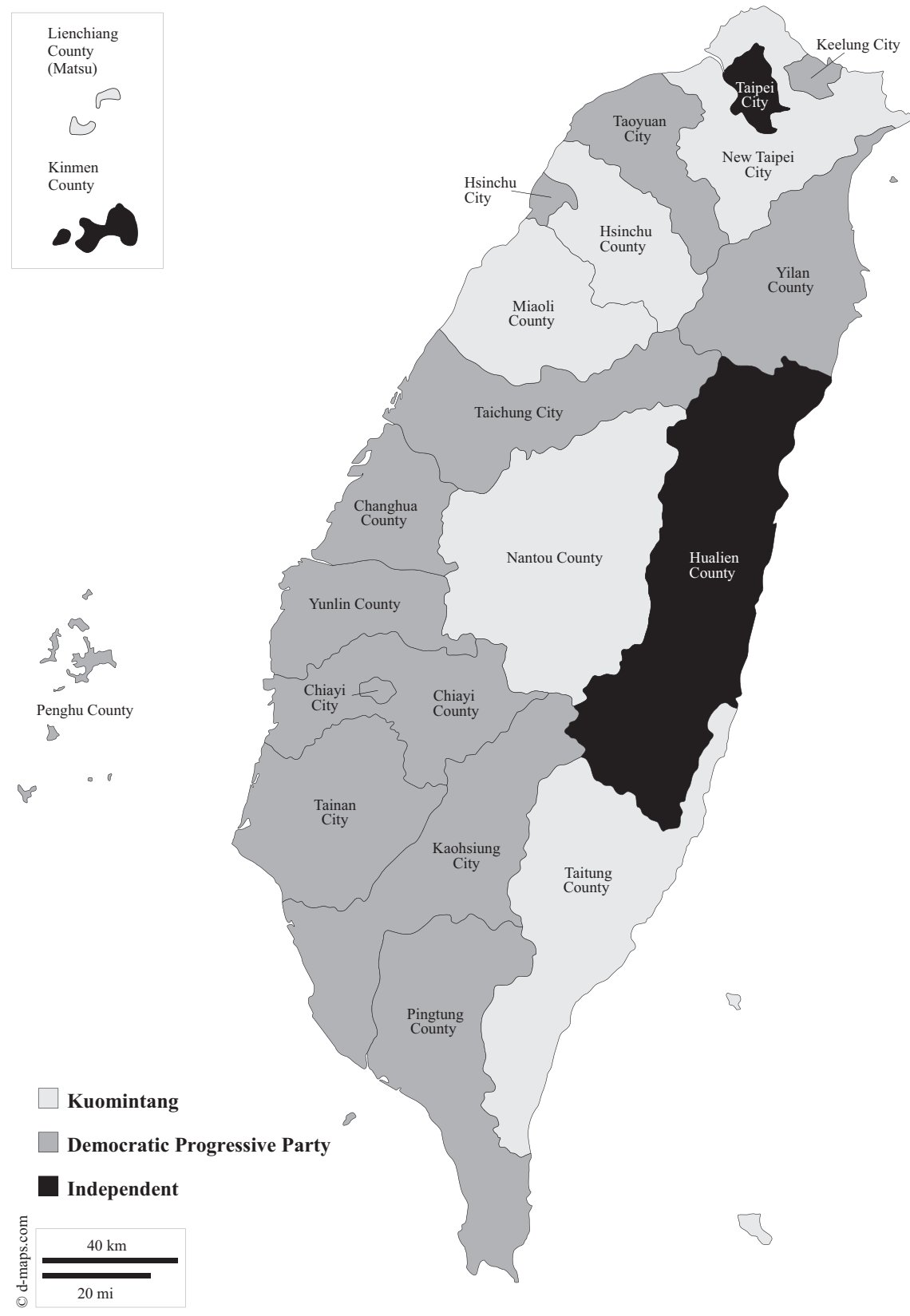

Source: Central Election Commission.

2010 vote numbers would have been enough to beat Chu in 2014 .

The election results in Taoyuan were a shock to most, since no poll or pundit had foreseen the defeat of the KMT in an apparently secured circumscription headed by the son of KMT old guard Hakka elder Wu Po-hsiung 吳伯雄. Taoyuan had just been upgraded to special municipality level, with a rising population, a real estate boom, and the economically transformative Aerotropolis mega project around the international Taoyuan airport. At the end of the day, John Wu Chih-yang 吳志揚 lost by 3\% to DPP candidate Cheng Wen-tsan 鄭文燦 while still improving the KMT's vote number. An unexpected jump in turnout, combined with a successful ground campaign by Cheng, led to a boost of almost $50 \%$ in his ballot numbers. The KMT trump cards in Taoyuan appeared to have all worked against it, and combined with anger among civil servants and military pensioners over Ma's policies toward them (a factor that also played in other municipalities) and a subtle demographic shift gave the victory to the DPP. The rise of new residents and voters, many pushed out of Taipei and New Taipei by sky-high housing prices, and the extensive land expropriations planned to realise the big business and construction companies' commercial dream of the Aerotropolis, combined with the local administration's high-handed attitude toward the common people and its corruption and profiteering scandals worked together to create a large movement against the KMT candidate's projects and re-election.

In Taichung, Jason Hu's re-election chances were always seen as small, the KMT elder being the city and then municipality head since 2001 and barely re-elected in 2010. Beyond a congenial personality, his job approval rating was low due to few improvements in urban life during his mandates, especially in transportation, and corruption and security issues in a region known for collusion between local mafia and politicians. The huge realestate development that Hu presided over for more than ten years has redesigned the city (including an architectural gem opera house), but as in many other places in Taiwan contributed more to growing income inequality than to the welfare of local people. In any case, the victory of Lin Chialung was impressive for its depth and width across the municipality districts, improving the DPP's 2010 score by more than $8 \%$ with a slightly inferior turnout. The Taichung results seemed to indicate a direct shift of support from the KMT to the DPP, with Lin's increased vote numbers corresponding almost exactly to the addition of Hu's losses and new voters. Hu's humiliating score, a record low for the Blue camp in Taichung, likewise indicated the growing gap between the KMT's privileged older generation of leaders, mostly in their 60 s and above, and the rest of the population's needs and imagined community, both in campaign priorities and communication.

Mayoral election results in both Tainan and Kaohsiung were largely expected, the unknown being merely the size of the victories of the DPP's incumbent candidates, William Lai Ching-te 賴清德 and Chen Chu 陳菊, as well as the municipality council election results (see below). Neither disappointed their supporters in terms of record results. With a smaller electorate than in Taipei, New Taipei, and Taichung, Chen Chu earned the highest number of votes in the nation despite a lower turnout. She was also facing an apparently stronger candidate than Lai in former DPP Kaohsiung County governor Yang Chiu-hsing 楊秋興, who joined the KMT after a failed independent candidacy in 2010. As a result, the KMT increase in vote share actually hides a larger victory for Chen, who managed to attract most of Yang's 2010 voters. In Tainan, Lai did not even need to campaign, with the KMT candidate merely a figurehead with no platform or prospects. As in Kaohsiung, a lower turnout did not prevent the DPP can- 
Table 3 - Taiwan Local Elections Results 2005-2014

\begin{tabular}{|l|c|c|c|}
\hline & $2005-06$ (Combined) & 2009-10 (Combined) & $18,511,356$ \\
\hline Registered voters & $16,793,623$ & $17,774,584$ & $12,261,784$ \\
\hline Valid votes & $10,931,099$ & $11,939,049$ & 67.59 \\
\hline Turnout \% & 66.13 & 68.15 & $47.55(52.67)$ \\
\hline DPP (Total estimation Green Camp) \% & 43.27 & 48.20 & $5,830,106(6,458,235)$ \\
\hline DPP (Total estimation Green Camp) votes & $4,729,819$ & $5,754,891$ & $40.70(43.89)$ \\
\hline KMT (Total estimation Blue Camp) \% & 52.24 & 45.76 & $4,990,677(5,381,874)$ \\
\hline KMT (Total estimation Blue Camp) votes & $5,710,486$ & $5,463,570$ & 11.70 \\
\hline Independents \% & 4.49 & 6.03 & 720,192 \\
\hline Independents votes & 490,794 & $1,434,851$ \\
\hline
\end{tabular}

Source: Central Election Commission.

didate from increasing vote share and votes, while the KMT crumbled to an abysmal $27.10 \%$. Both circumscriptions highlighted the increasing conundrum of the KMT across the south, where the lack of appeal of its economic and national identity policies is reinforced by a shrinking pool of up-and-coming local politicians outside of the old local factions tied to corruption and scandals.

In terms of turnout, these elections provide very different pictures according to each locale. The $70.4 \%$ turnout in county and city elections shows a $4.6 \%$ rise compared to $2009,{ }^{(5)}$ probably benefiting from higher media exposure and national mobilisation generated by the merging of all local polls on the same day. For the six special municipalities, turnout decreased by $3.25 \%$, with sharper drops in New Taipei, Kaohsiung, and Tainan, almost no change in Taipei, and a rise in Taoyuan. The lower turnout may be explained by the expected victory of the incumbents in the first three municipalities. But since both Kaohsiung and Tainan saw the vote numbers of their popular DPP candidates jump, together with a large increase in DPP votes in Taichung and Taoyuan, the Green electorate was clearly very enthusiastic about voting and sending a message to the Ma administration. The main reason for a moderate turnout is thus probably due to higher abstention among Blue voters, out of either a wish to sanction the KMT or an inability to support its candidates.

At the level of city and county councils, the DPP also made marked gains and for the first time equalled the KMT in terms of percentage, with the DPP winning $37.08 \%$ and the KMT $36.86 \%$ of the vote, the rest being shared by smaller parties and independents. In terms of seats, however, the KMT still dominates the councils nationwide with 386 seats versus 271 for the DPP. In the special municipalities, the Green camp was potentially in control after the council polls in New Taipei, Tainan, and Kaohsiung, while significantly raising its councillor numbers in Taipei, Taoyuan, and Taichung. The election of council chiefs by councillors in early January nevertheless saw the Blue camp winning in New Taipei and Tainan, leading to new rounds of bribery accusations against the KMT and judicial investigations. ${ }^{(6)}$ Council elections also witnessed the first success of candidates from small parties such as the Green Party (Taiwan lüdang 台灣绿黨), the Tree Party (Shudang 樹黨), and the indigenous peoples' First Nations Party (Taiwan diyi minzu dang 台灣第一民族黨).

Finally, in the elections for city mayors and township chiefs, the KMT only barely maintained its traditional dominance in votes, with $33.71 \%$ versus $31.72 \%$ for the DPP, winning 80 seats, followed by 68 independent seats, and 54 DPP seats.

\section{Analysis of the election results}

The tremendous defeat of the KMT nationwide and in the most important contests coincides with a continuous downslide from its past dominance at the lower rungs of elected positions. In this respect, the DPP certainly benefited from the low popular support for $\mathrm{Ma}$ and his administration, but the poll results also confirm significant medium-term political shifts and a protest vote that were not understood by many analysts, and may foretell more change in future electoral behaviour. This can be assessed by comparing these elections with the aggregated results of two former rounds of local elections in 2005-06 and 2009-10 (see Table 3). In the past ten years, the DPP vote share has grown almost $10 \%$, with an increase of around $4.5 \%$ per election cycle, from $43.27 \%$ in $2005-06$, to $48.20 \%$ in $2009-10$, and to a virtual minimum of $52.67 \%$ in 2014 . Meanwhile, the drop in KMT support has been proportional, the party and its allies losing more than $8 \%$ since 2005-06 (52.24\% to $45.76 \%$ to $43.89 \%$ ), which should ring alarm bells in the party, as local dominance is crucial to maintaining national-level election success.

\section{Reasons behind the KMT defeat}

The reasons behind the KMT election results are diverse but mostly linked to the domestic situation. The elections remained local contests and did not imply a direct judgment on cross-strait and international policies. Outside factors such as relations with China and the Hong Kong Umbrella movement did not play substantial roles, even though Hong Kong's political evolution has reinforced the rejection by most Taiwanese of any future unification with the People's Republic of China and their long-held view

5. Number adjusted for the switch of Taoyuan to special municipality level.

6. All together, 167 elected officials have been charged by prosecutors for vote-buying, corruption, and other electoral crimes in the elections, including the main protagonists in the Tainan and New Taipei council election scandals. Cf. Jason Pan, "Over 150 officials face charges after Nov. 29 elections," Taipei Times, 7 January 2015. 
of the fallacy of the "One country, Two Systems" (yiguo liangzhi一國兩制) policy. But its countrywide nature, its political nationalisation by the KMT, and the anti-KMT wave clearly gave a national dimension to the poll. It allowed voters to express dissatisfaction toward Ma Ying-jeou's administration and policies, including cross-strait policies, and sent a strong message to the government to readjust its priorities, while the KMT itself has been deeply split since 2013 by infighting led by the president and his close associates.

The main reproach of the electorate touches on the dismal economic situation of the majority, and especially of the younger generation, despite a nominal annual GDP growth of $2 \%-3 \%$ in recent years. Since Ma's economic policies from the start of his first term in 2008 have focused on China and cross-strait integration, ${ }^{(7)}$ the poll results also carried a strong rejection of the government's central economic program. The Sunflower Movement (taiyanghua yundong 太陽花運動 or 3-18 三一八 movement), which prevented ratification of the CSSTA (Cross-strait Service Trade Agreement haixia liang'an fuwu maoyi xieyi 海峽兩岸服務貿易協議) signed in 2013, was already a signal to the government that the majority of Taiwanese were not benefiting from closer relations with China and feared even more intrusion from and control by Chinese businesses and political interests in their lives and the nation's economy, especially at the small and medium enterprise level. Economists and official audits have recognised that the ECFA cross-strait agreement (Economic Cooperation Framework Agreement liang'an jingji hezuo jiagou xieyi 兩岸經濟合作架構協議) the prelude to the CSSTA, has not brought much tangible GDP growth or benefit to most Taiwanese, and often the opposite. ${ }^{(8)}$ Tourist venues flooded with uncouth Chinese tour groups whose spending benefits mainly Hong Kong and Chinese tourism companies, compounded by illegal Chinese investment in residential real estate ${ }^{(9)}$ and overt pro-China propaganda by KMT-affiliated tycoons and Taishang 台商 (Taiwanese doing business in China), have provided a disastrous image of the very practical consequences of rapprochement with China.

The government's self-righteous attitude and police brutality in dealing with the Sunflower Movement and previous civil and social movements were also largely disapproved of by public opinion. But criticism of the government did not stop at cross-strait policies. Even more important were the growing income gap and repeated expressions of incompetence, political autism, and shoddy work by KMT central and local governments. Across the country, rising discontent with land speculation, overt corruption or the appearance of official impropriety and collusion with big business, inadequate or impotent administration policies, disconnection with and blatant disregard for common people's needs and lives, including inefficient laws and lackadaisical monitoring of food safety, industrial accidents, and pollution threatening everybody's health and daily life, KMT officials' sense of entitlement, their rising authoritarian tendencies, the growing politicisation and partisan use of state institutions (from various ministries and agencies to police and justice), and deficient or nonexistent social policies have all increasingly fuelled popular rejection of the KMT administration. This all played out against a background of non-redistributive growth and increasing economic disparity with decreasing or stagnating low salaries for the majority, rising prices for basic utilities and food products, exorbitant real-estate cost and speculation, an unbalanced tax system, and the upper and ruling classes getting richer in a typical plutocratic configuration. Discontent toward Ma Ying-jeou personally and toward his successive administrations has thus spread across the political spectrum, even in the Blue camp, and is very strong among the middle and young voters. ${ }^{(10)}$
Finally, the defeat of the KMT old guard and pro-China political family candidates in Taipei, Taoyuan, and Taichung expressed the electorate's disaffection for old-style politics as well as the lack of new blood and grooming of younger politicians outside the party's entrenched factions. This contrasts with the DPP, which has focused much of its effort since losing power in 2008 on local governance, community work, on-the-ground networking, and training or supporting a new generation of grass-root politicians, including some involved in the Sunflower and previous social movements. These efforts seem to have started repaying the party with a much higher number of elected councillors who are female and under 35 as compared with the KMT.

\section{The Ko Wen-je phenomenon}

The victory of the independent candidate Ko Wen-je as Taipei's mayor was also a major event of the elections. Ko represents a new phenomenon in Taiwan's political landscape. Criticising the Blue-Green rivalry as sterile, Ko vowed to free city affairs of political polarisation by picking competent politicians and administrators from both camps, and to run an efficient and transparent government open to public participation. This struck a chord among the capital's middle voters and younger generation, who often don't recognise themselves in the old Blue-Green battles. Ko's campaign team and the new city administration have thus been staffed by NP, PFP, and DPP politicians, as well as non-partisan professionals and activists. Considered to hold deep Green convictions, and coming from a family victimised during the 1947 2-28 incident, Ko focused his message on the future and youth rather than on the past, and praised PFP leader Soong Chu-yu for his administrative competence. He also achieved the rare feat of defending Republic of China sovereignty against "KMT compradors" while challenging the meaning of the so-called 1992 consensus and keeping a business-as-usual attitude toward China, where he has frequently travelled and lectured. Run on a shoestring, the campaign kept a positive tone and made the best use of social media, activist groups, and free publicity through the mainstream media's constant reporting on his contest with Lien. Hard to pigeonhole, his blunt, humorous, no-nonsense, fact-based, and result-oriented style convinced voters that this non-conventional candidate could better turn the city to the service of its residents and straighten out a series of controversial infrastructure and construction projects pursued by previous administrations. In many ways, despite an authoritarian tendency that has already been criticised, Ko makes other candidates and politicians look a bit pale, indecisive, and disconnected from the public pulse, and may provide new standards for future national and local politicians and campaigns starting in 2016.

7. Cf. Frank Muyard, "Taiwan Elections 2008: Ma Ying-jeou's Victory and the KMT's Return to Power," China Perspectives, 73 (2008/1), pp. 79-94, and Frank Muyard, "Mid-Term Analysis of the Ma Yingjeou Administration: The Difficulty of Delivering the (Right) Goods," China Perspectives, 83 (2010/3), pp. 5-21.

8. Tung Chen-yuan, "ECFA bringing only limited benefits," Taipei Times, 19 May 2013; Hsiang-Yi Chang, "Demystifying ECFA: The Early Harvest List, 3 Years On," CommonWealth Magazine, No. 546, 2 May 2014, http://english.cw.com.tw/article.do?action=show\&id=14757 (accessed on 26 January 2015); Lee Hsin-fang, "ECFA benefited trade little: Ministries," Taipei Times, 17 August 2014; Du Yu, "ECFA gutted nation's fishery sector," Taipei Times, 8 September 2014.

9. Yimou Lee and Faith Hung, "Anger flares as mainland Chinese muscle in on Taiwan property," Reuters, 12 August 2014.

10. Scathing criticism of the president in recurrent editorials by the pro-unification newspaper United Daily News offers a good sense of the general discontent of the nation; for instance "Zhenzuo dian! Boya zongtong bubi zuokun choucheng," Lianhebao shelun, 13 January 2015, http://udn.com/news/story/7338/638788 (translated in English as, "Cheer up! A lame duck president need not sit and brood," Dateline Taipei, http://datelinetaipei.blogspot.tw/2015/01/cheerup-lame-duck-president-need-not.html) (both links accessed on 26 January 2015). 


\section{Poll outcomes}

An immediate aftermath of the KMT defeat was the resignation of premier jiang Yih-hua 江宜樺, and then, after heavy public and insider pressure, the forced resignation of Ma Ying-jeou as party chairman amid promises of reform and listening to public views. An almost identical new cabinet under Mao Chi-kuo 毛治國, another technocrat and close associate of Ma who pledged to pursue the same policies, immediately belied these engagements. Already deeply unpopular and unable to pass its priority bills in a KMT-controlled but restive parliament, the government should remain in caretaker mode until the 2016 national elections. At the party level, the new chairman, Chu Li-luan, will also have to implement more than superficial changes to convince a suspicious electorate that he is willing and able to reform a party deeply divided between factions and entrenched interests, and to regain the trust of the middle voters. The 2016 legislative and presidential elections will be decided on more national issues and policies, with the China factor looming large, but they are approaching fast, and the evolution of the electorate is not favourable to the KMT.

The November elections seemed indeed to mirror the anti-DPP protest vote in the 2005 local and 2008 national elections, this time at the expense of the Kuomintang, and for similar reasons of disillusion and distrust of a government out of touch with people's priorities. This time again, economic voting was preeminent, as well as the rejection of an administration deemed unresponsive, in questionable alliances with big business, and too intent on imposing its will and China-centred ideology on the public instead of working to alleviate the economic plight of the middle and lower classes.

The polls also attested to the significance of the middle non-partisan voters, who proved once again that they hold the key to elections in Taiwan. Their political stands include a dislike for ideological and radical policies, support for middle-of-the-road positions, social equality, and pro-middle class policies, and a pragmatic stance on economic measures based on their results. They like independent, even populist, candidates and avoid ideological choices, and when disappointed they may withdraw their support en masse or use their vote to punish parties and governments. In past years, the share of self-identified independent voters has tended to grow markedly in opinion polls, mainly at the expense of the KMT, which has lost the image of a moderate party that brought Ma to power.

As a consequence, the KMT's hold on the electorate seems to have been largely broken. The Blue camp poll results were for the first time below its traditional base of $45 \%$ of the national vote, and opinion polls indicate that it has lost the middle, urban, educated, and young electorate. The younger generation seemed to have voted in significant numbers against Ma's administration and policies, a worrying sign for the party's future. The number of registered voters continues to grow, with an increasing proportion of a younger generation raised under democracy, and whose political awakening corresponded to the two terms of Ma's administration, joining the ranks of voters.

Finally, previous regional elections under a second-term president have all signalled an electoral shift that was confirmed in the subsequent presidential elections. Barring major changes in the political landscape or failure to maintain its unity and good local governance, the DPP appears to be in a favourable position for 2016. Its control of four municipalities and the centre (Taichung, Changhua) may be crucial to consolidate its local elections win at the national level. But it will need more palatable platforms for cross-strait and international policies than in 2012, and must find ways to respond to the economic worries of the electorate. Both parties' choice of presidential candidates, to be decided by primaries in 2015, will also have a bearing on the outcome in a very personality-focused media culture, as well as on the direction of Taiwan politics in the rapidly approaching post-Ma era.

I Frank Muyard is a Sociologist and Sinologist, currently Assistant Professor, National Central University, Taiwan, and Associate Researcher at the French Centre for Research on Contemporary China (CEFC).

Department of French Studies, National Central University, Taoyuan, Taiwan (frank.muyard@gmail.com). 